\title{
Review of sheep and goat pox disease: current updates on epidemiology, diagnosis, prevention and control measures in Ethiopia
}

\author{
Girma Zewdie $^{1 *}$ (D), Getaw Derese ${ }^{1}$, Belayneh Getachew ${ }^{1}$, Hassen Belay ${ }^{2}$ and Mirtneh Akalu ${ }^{3}$
}

\begin{abstract}
Sheep pox, goat pox, and lumpy skin diseases are economically significant and contagious viral diseases of sheep, goats and cattle, respectively, caused by the genus Capripoxvirus (CaPV) of the family Poxviridae. Currently, CaPV infection of small ruminants (sheep and goats) has been distributed widely and are prevalent in Central Africa, the Middle East, Europe and Asia. This disease poses challenges to food production and distribution, affecting rural livelihoods in most African countries, including Ethiopia. Transmission occurs mainly by direct or indirect contact with infected animals. They cause high morbidity (75-100\% in endemic areas) and mortality (10-85\%). Additionally, the mortality rate can approach $100 \%$ in susceptible animals. Diagnosis largely relies on clinical symptoms, confirmed by laboratory testing using real-time PCR, electron microscopy, virus isolation, serology and histology. Control and eradication of sheep pox virus (SPPV), goat pox virus (GTPV), and lumpy skin disease (LSDV) depend on timely recognition of disease eruption, vector control, and movement restriction. To date, attenuated vaccines originating from KSGPV O-180 strains are effective and widely used in Ethiopia to control CaPV throughout the country. This vaccine strain is clinically safe to control CaPV in small ruminants but not in cattle which may be associated with insufficient vaccination coverage and the production of low-quality vaccines.
\end{abstract}

Keywords: CaPV, Ethiopia, GTPV, Sheep pox, Goat pox, SPPV, Vaccine

\section{Introduction}

Livestock production has massive potential to achieve several of Ethiopia's national and international assurances on poverty mitigation, food security, and improved nutrition. The economic contribution of the livestock subsector in the country is approximately $45 \%$ of the total worth of agricultural production (FAO 2019). Ethiopia is the home of the largest livestock population in Africa and has an estimated 39.89 million sheep, 50.50 million goats, and 65.35 million cattle. Thus, small ruminants (sheep and goats) are important components

\footnotetext{
* Correspondence: girmazewdie19@gmail.com

${ }^{1}$ National Veterinary Institute, P. O. Box: 19, Bishoftu, Ethiopia

Full list of author information is available at the end of the article
}

of the subsector and have been supporting the national economy of the country by generating hard currency from meat exports (CSA 2020). Likewise, this sector constitutes a significant portion of livestock production and is a source of cash income, meat, milk and wool for small farm holders (Haile et al. 2018).

Despite the huge livestock population, the current economic contributions of small ruminants in Ethiopia have not delivered the expected benefit to the national economy because of widely distributed infectious diseases of small ruminants such as sheep pox (SPP) and goat pox (GTP). These diseases are the main constraints that hinder the productivity of sheep and goats. Additionally, these diseases pose major economic threats globally,

(C) The Author(s). 2021 Open Access This article is licensed under a Creative Commons Attribution 4.0 International License, which permits use, sharing, adaptation, distribution and reproduction in any medium or format, as long as you give appropriate credit to the original author(s) and the source, provide a link to the Creative Commons licence, and indicate if changes were made. The images or other third party material in this article are included in the article's Creative Commons licence, unless indicated otherwise in a credit line to the material. If material is not included in the article's Creative Commons licence and your intended use is not permitted by statutory regulation or exceeds the permitted use, you will need to obtain permission directly from the copyright holder. To view a copy of this licence, visit http://creativecommons.org/licenses/by/4.0/ The Creative Commons Public Domain Dedication waiver (http://creativecommons.org/publicdomain/zero/1.0/) applies to the data made available in this article, unless otherwise stated in a credit line to the data. 
particularly in developing countries such as Ethiopia (Fentie et al. 2017).

SPP and GTP are typically infectious and economically significant viral diseases of sheep and goats in several parts of the world. They are manifested by widespread pox lesions across the skin and mucous membranes, constant fever, enlargement of superficial lymph nodes, pyrexia, generalized nodules (2 to $5 \mathrm{~cm}$ in diameter) on nonwool skin, generalized pocks, and often focal viral pneumonia (Bhanuprakash et al. 2011; Şevik et al. 2016). Therefore, the current review aims to discuss the effective control of SPP and GTP and highlight the current status of these diseases and their epidemiology, diagnosis and treatment.

\section{Literature review}

\section{Etiology}

Sheep pox, goat pox, and lumpy skin disease are economically important infectious diseases of sheep, goats and cattle, respectively. They belong to the genus Capripoxvirus (CaPV), in the subfamily Chordopoxvirinae and Poxviridae family (King et al. 2012). Sheep pox virus (SPPV) and goat pox virus (GTPV) are intimately linked to the lumpy skin disease virus (LSDV) of cattle and mainly affect sheep and goats, respectively. However, some virus isolates may cause mild to severe disease in both species; hence, these strains generally have transitional host specificity (Babiuk et al. 2008; Tuppurainen et al. 2014).

The central core of the virion contains genome and many viral proteins, while the capsid surrounds the core and two lateral bodies (Moss et al. 2006). The genome size of CaPV is relatively constant ( $150 \mathrm{kbp})$. Additionally, the genome comprises large, brick-shaped, complex, double-stranded DNA and enveloped viruses (Biswas et al. 2020). It contributes approximately 150 putative genes, together with conserved genes engaged in virulence and host ranges, as well as conserved replicative and structural genes. Most of the genes in the central genomic region of $\mathrm{CaPV}$ are responsible for replicative mechanisms, while the terminal region contains genes that influence pathogenesis and host range functions (Zeng et al. 2014). A false lipid envelope surrounds the genome of $\mathrm{CaPV}$ and can be affected by many disinfectants and acids (Hosamani et al. 2004). The replication of CaPV occurs in the cytoplasm of infected cells rather than in the nucleus, a rare occurrence for viruses with double-stranded DNA genomes (Schramm and Locker 2005).

Because only a single serotype of CaPV exists, distinguishing among SPPV, GTPV and LSDV is challenging using serological techniques (Babiuk et al. 2008; Bowden et al. 2008) and antigenic (Babiuk et al. 2008) techniques. However, genetic sequencing and phylogenetic investigation of the GPCR (G-protein coupled receptor) and RPO30 subunit genes encoding the $30 \mathrm{kD}$ genes have been developed to discriminate among LSDV, GTPV and SPPV (Lamien et al. 2011). P32, GPCR and RPO30 genes are highly conserved among capripoxviruses (Venkatesan et al. 2012; Mahmoud and Khafagi 2016).

Following the analysis of SPPV or GTPV, the losses of 5 open reading frames (ORFs) (Biswas et al. 2020) and deletion of 21 nucleotides in the RPO30 gene of SPPV were reported (Rouby 2018). Additionally, the $B 22 R$ gene portion showed deletion in the SPPV Romania strain compared with that in GTPV and LSDV (Chibssa et al. 2019). Hence, these findings revealed that GTPV is more closely linked to LSDV than SPPV (Le Goff et al. 2009; Lamien et al. 2011).

\section{Susceptible hosts}

Sheep and goats are vulnerable to SPP and GTP. Many of the strains studied cause severe disease in either sheep or goats, but some have equivalent pathogenic effects in both species (FAO 2017b). By contrast, LSDV affects cattle and domestic Asian water buffaloes, but it does not naturally infect sheep and goats. However, some strains of LSDV can replicate in sheep and goats. Additionally, no epidemiological confirmation exists concerning the role of sheep and goats as reservoirs for LSDV (Tuppurainen et al. 2018). In Ethiopia, GTPV and LSDV have been reported for CaPV outbreaks in small ruminants and cattle, respectively, whereas SPPV is absent (Gelaye et al. 2015). Additionally, according to Kenubih et al. (2021), GTPV has been accountable for the occurrence of $\mathrm{CaPV}$ diseases in small ruminants. Currently, no decisive confirmation exists that SPPV, GTPV (FAO 2017b), and LSDV can affect humans (OIE 2010; Haller et al. 2014).

\section{Epidemiology \\ Geographic distribution}

$\mathrm{CaPV}$ infections in small ruminants have a global distribution and are wider than LSD (Fig. 1A). The distributions of $\mathrm{CaPV}$ in small ruminants are relatively stable. Numerous studies and reports suggest that SPP and GTP viruses are highly distributed in northern and central Africa, the Middle East, Europe and Asia (Tuppurainen et al. 2017). However, LSDV has significantly increased in Asia, including Russia, China, India, Thailand, Malaysia, Sri-Lanka, Bangladesh and Vietnam (Fig. 1B) (FAO 2017a; Hamdi et al. 2021), and frequent outbreaks of LSD in Greece were reported in the past, with occasional outbreaks of LSD in Bulgaria due to outbreaks that occurred in Turkey (OIE 2008).

Sporadic outbreaks of SPP and GTP have been reported in Southern Europe (Rao and Bandyopadhyay 2000). During 2013, the most recent disease outbreaks 

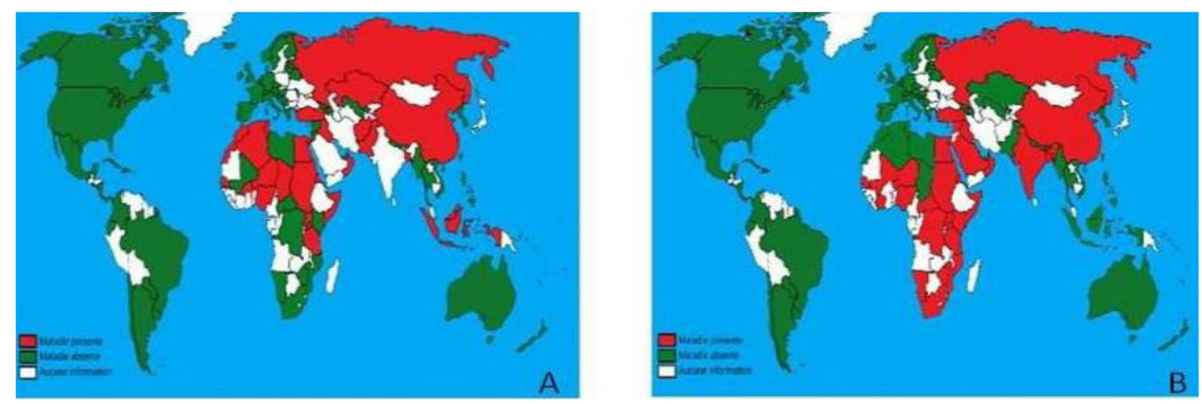

Fig. 1 A Sheep pox geographic distribution. B Lumpy skin disease geographic distribution. Source: (Hamdi et al. 2021). The red color indicates the presence of CaPV

were recorded in Bulgaria and Greece, Israel in 2014, and Russia and Mongolia in 2015 (Tuppurainen et al. 2017). In Ethiopia, very limited investigations have been conducted on sheep and goat pox virus in selected parts of the country (Gari et al. 2015). However, the diseases have a widespread distribution in all regional states of the country and affect the production and productivity of the subsector in the country. In the Gondar veterinary clinic, the prevalence was $40 \%$ in sheep and $8.12 \%$ in goats (Molla et al. 2017a); in the Gamo Gofa zone of the country, the prevalence was $31.96 \%$ in sheep and $35.28 \%$ in goats (Kebede et al. 2018). Recently, seroprevalence epidemiological studies have been performed on sheep and goat pox. However, the spatiotemporal clustering of SPP and GTP incidence rates has not been studied (Aregahagn et al. 2021).

\section{Host-specificity}

Maksyutov et al. (2015) reported that most CaPV strains are highly host-specific, with only some exceptions (Maksyutov et al. 2015). Thus, SPPV isolates cause disease mainly in sheep, and GTPV isolates cause disease primarily in goats (Bhanuprakash et al. 2010). However, both species of small ruminants may acquire the disease from a single strain of the virus. Some sheep strains cause mild disease in goats and severe disease in sheep, whereas virulent goat strains can infect sheep (Bhanuprakash et al. 2010; He et al. 2020). Thus, CaPVs are cross-reactive within the genus Capripoxvirus (Tuppurainen et al. 2014). SPPV and GTPV can cause crossinfection either naturally or experimentally (Davies 1982). However, no evidence has supported that LSDV can cause disease in small ruminants (USDA 2016).

\section{Transmission}

Transmission of CaPV is mainly considered by either direct contact with contaminated respiratory droplets or indirect contact through contaminated environments and vectors (Sprygin et al. 2019). However, these viruses are viable for extended periods in the environment.
Thus, the movement of contaminated animals acts as the most important reason for the transmission of the agents (Rao and Bandyopadhyay 2000; Verma et al. 2011). Experimentally, sheep and goats have been infected with intradermal (Bowden et al. 2008) and intranasal inoculation of the respective viruses (Balinsky et al. 2007). According to Bhanuprakash et al. (2006), stable flies were confirmed to transmit SPP and GTP viruses mechanically.

\section{Morbidity and mortality rates}

SPPV and GTPV cause major economic disasters because of the relatively high morbidity and mortality of vulnerable animals. Thus, in endemic areas, the morbidity is between $75 \%$ and $100 \%$ and between $10 \%$ and $85 \%$ based on the virulence of the isolates (Bhanuprakash et al. 2006). Additionally, the mortality rate can reach up to $100 \%$ in stressed and susceptible animals (Domenech et al. 2006) but usually ranges from $5 \%$ to $10 \%$ in local breeds (Bhanuprakash et al. 2006).

Additionally, morbidity and case fatality rates of approximately $20 \%$ and $40 \%$ have been reported, respectively (Beard et al. 2010), while the mortality rate is not very high (up to 10\%) because of LSDV (Calistri et al. 2018). In Ethiopia, SPPV and GTPV are highly distributed in all regions of the country and cause huge production losses and mortality (Yune and Abdela 2017). Species, stress, coexisting infection, breeds, age, host immunity, and virus isolates may all influence disease morbidity and mortality (Babiuk et al. 2009a; Tuppurainen et al. 2017). Native breeds are more resistant to CaPV than European breeds. Young animals are generally at greater risk than adults because of extensive interstitial viral pneumonia (Kitching et al. 1986).

\section{Economic Importance of sheep and goat pox}

Certain infectious diseases, such as SPP and GTP, are the most important viral diseases of small ruminants that cause severe production losses in sheep and goats in the diseases' respective endemic areas. The disease also 
limits international trade and causes other economic losses (Tuppurainen and Oura 2012; Hopker et al. 2019). Hence, the World Organization for Animal Health (OIE) has classified CaPV as a notifiable disease because of their rapid transboundary nature and extensive economic impact on the livestock industry (Tuppurainen and Oura 2012; Zeng et al. 2014; Hamdi et al. 2021). Similarly, these economically devastating viral diseases affect sheep and goats. Globally, the disease causes a serious risk to small ruminant production and food security and jeopardizes international trade (Tuppurainen et al. 2015).

Furthermore, CaPV can cause significant economic losses due to control costs and trade restrictions. In an endemic area, the economic losses of SPP and GTP have been reflected by reduced milk and mutton production, decreased weight, abortion, significant harm to wool and hides, and vulnerability to pneumonia and fly strike. The disease's direct economic impacts are primarily due to higher morbidity rather than mortality in susceptible animals (Al-Salihi and Hassan 2015; Molla et al. 2017b). In India, the estimated morbidity and death rates of $63.5 \%$ and $49.5 \%$ were reported, respectively, for sheep and goat production (Bhanuprakash et al. 2011). However, a significant decrease in milk production (up to 30\%), an increased death rate in experimentally infected animals (up to $95 \%$ ), and a decrease in conception rate following the outbreak of the disease in Israel have been observed (Yeruham et al. 2007).

Depending on the current scenario in Ethiopia, small ruminant production is a basic source of income and food for the small farmholder community in the country, and it has a high potential for foreign exchange earnings. Additionally, small ruminant production is considered a savings sector for smallholder farmers in addition to a source of income and food because it eliminates threats to disadvantaged communities in the absence of crop production due to natural disasters. Furthermore, other socioeconomic and cultural functions are involved for small-holder households. During 2010/11, export values of 63 million USD from meat and 148 million USD from live animals were acquired from small ruminants (Haile et al. 2018).

Similarly, the present exploitation of hides and skins is expected to be $75 \%$ for goat skin and $97 \%$ for sheep skin, with the estimated annual off-take rates of sheep and goats of $33 \%$ and $35 \%$, respectively. The country supplies many finished and semifinished small ruminant hides and skins to the global market and accounts for approximately $12-16 \%$ of the total value of its exports (Yacob et al. 2008; Zemene and Mekonnen 2012). Several factors, however, such as sheep and goat CaPV, have hampered the sector's development in the country (Yune and Abdela 2017; Kenubih et al. 2021).
Furthermore, a lack of detailed information or insufficient information has contributed substantially to the prevalence of SPP and GTP in Ethiopia. Consequently, 893 outbreaks were reported in $2007 / 08$. Of these eruptions, 57638 small ruminants became sick, among which 6401 (11.1\%) died (Entity 2016). Additionally, from 2010 to 2014,366 outbreaks were reported. Of these eruptions, 12822 were sick, and 1480 died of sheep pox; from 182 outbreaks, 10066 were infected, and 997 deaths were reported from goat pox in the Amhara Regional State (Fentie et al. 2017).

Furthermore, the annual economic losses due to mortality range from 12 to $14 \%$ for sheep and 11 to $13 \%$ for goats, as reported previously (MOA 2013). Hence, these diseases present major limitations to global trade and prevent the introduction of improved breeds of animals into endemic regions, being responsible for a significant economic impact on the animal industry in Ethiopia. These diseases are more severe in the lowland than in the midland and highland agro-ecologies of the country (Fentie et al. 2017).

\section{Diagnosis}

\section{Clinical diagnosis}

Clinically, it is difficult to distinguish SPP from GTP based on symptoms, lesions, and postmortem lesions (Bowden et al. 2008). Additionally, in the field, many clinical and pathological manifestations are recognized because of variations in the host response, virus species and virulence of the viral strains (Sumana et al. 2020). The incubation time differs from 4 to 21 days (Gitao et al. 2017); however, it is generally 21 days (OIE 2010). In general, CaPV infections have similar clinical manifestations (Rao and Bandyopadhyay 2000).

Initially, the lesions appear as papules and further progress to nodules, vesicles and pustules (raised lesions); finally, scab formations are detected on the skin (Babiuk et al. 2008; Bhanuprakash et al. 2006). Most affected animals become weak and lose appetite, have a high fever $\left(40-42{ }^{\circ} \mathrm{C}\right.$ ), and find it difficult to breathe because of the presence of blisters inside their respiratory tract and lungs (Bowden et al. 2008). Skin lesions are visible on the entire body of infected animals but can be easily seen on hairless areas. Lesions (mouth, nose and eyelids), nasal discharge, and extreme salivation (Fig. 2) occur. Mucous membranes become necrotized and ulcerative. The presence of nodules in the intestine leads to diarrhea (Rao and Bandyopadhyay 2000; Haller et al. 2014).

\section{Differential diagnosis}

SPP and GTP may be confused with contagious ecthyma, dermatophilosis, sheep scab, urticaria, parasitic pneumonia, and mange. However, in severe cases, 


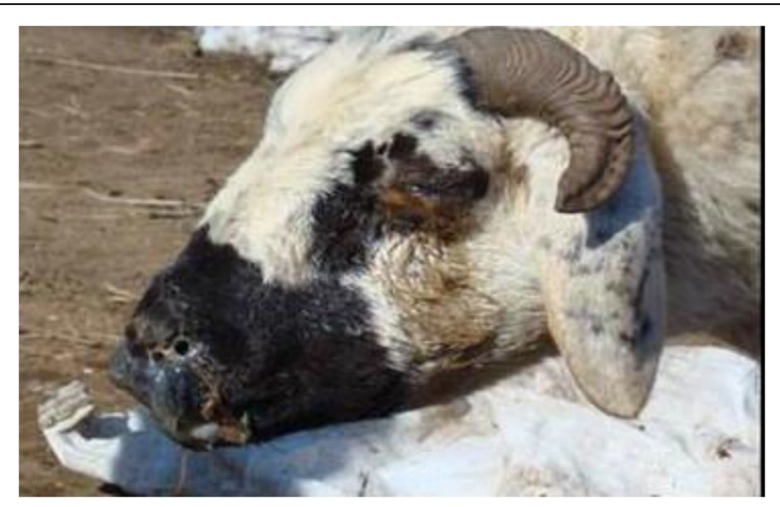

Fig. 2 Thick discharges from the nose, nostrils and eyes. Source: (Mirzaie et al. 2015)

clinical signs are highly characteristic. Additionally, a simultaneous infection with orf and peste des petits ruminants can cause the clinical signs of SPP or GTP with skin lesions occurring from orf and lung lesions and nasal discharge from PPR (OIE 2008).

\section{Pathology and post-mortem diagnosis \\ Gross lesions}

At postmortem examination, Pox lesions were distributed throughout the lung, kidney, heart (Fig. 3), and digestive and respiratory tracts.

Popular lesions were also accumulated over the hairless areas of infected animals, such as the tail (Fig. 4A), face and ear (Fig. 4B). Additionally, lesions were detected throughout the entire body, including on the tail, face, lips, nose, muzzle, eyelids, ear, flank, abdomen, vagina, udder and all limbs (Gitao et al. 2017).

\section{Histopathological lesions}

In a histopathological study, the affected parts of the skin layers (epidermal and dermal changes) were characterized by hyperkeratosis, acanthosis, hyperkeratinization, edema, degenerative changes of sebaceous glands and hair follicle-affected parts (Pham et al. 2020). Pham et al. (2020) and Afshar et al. (1986) also reported pulmonary lesions and proliferative alveolitis with infrequent cytoplasmic inclusions in alveolar cells and macrophages.

Furthermore, sheep and goats were inoculated with SPPV and GTPV in their respective homologous hosts for detailed histopathological examinations. A monoclonal antibody generated from SPPV was utilized for immunohistochemical detection of viral antigen. Lesions and antigens were reported constantly in the skin, lung and lymph nodes. In general, recent histological findings revealed similarities between monkey pox and smallpox. Thus, CaPV infection in small ruminants may be a useful model to research strategies for poxvirus-specific virus vaccine conceptions and therapeutics (Embury-Hyatt et al. 2012).

Laboratory diagnosis is necessary to confirm the disease, and the following methods are used. It includes serological tests such as serum neutralization tests (more sensitive and specific gold standard) (Wolff et al. 2020), indirect fluorescent antibody test (IFAT), enzyme-linked immunosorbent assay (ELISA), and agar gel immunodiffusion assay (AGID) (Milovanović et al. 2019). Virus neutralization tests (VNTs) are the gold standard technique (Haegeman et al. 2016). However, VNT may not detect low levels of antibodies from vaccinated animals (Babiuk et al. 2009b; Gari et al. 2008).

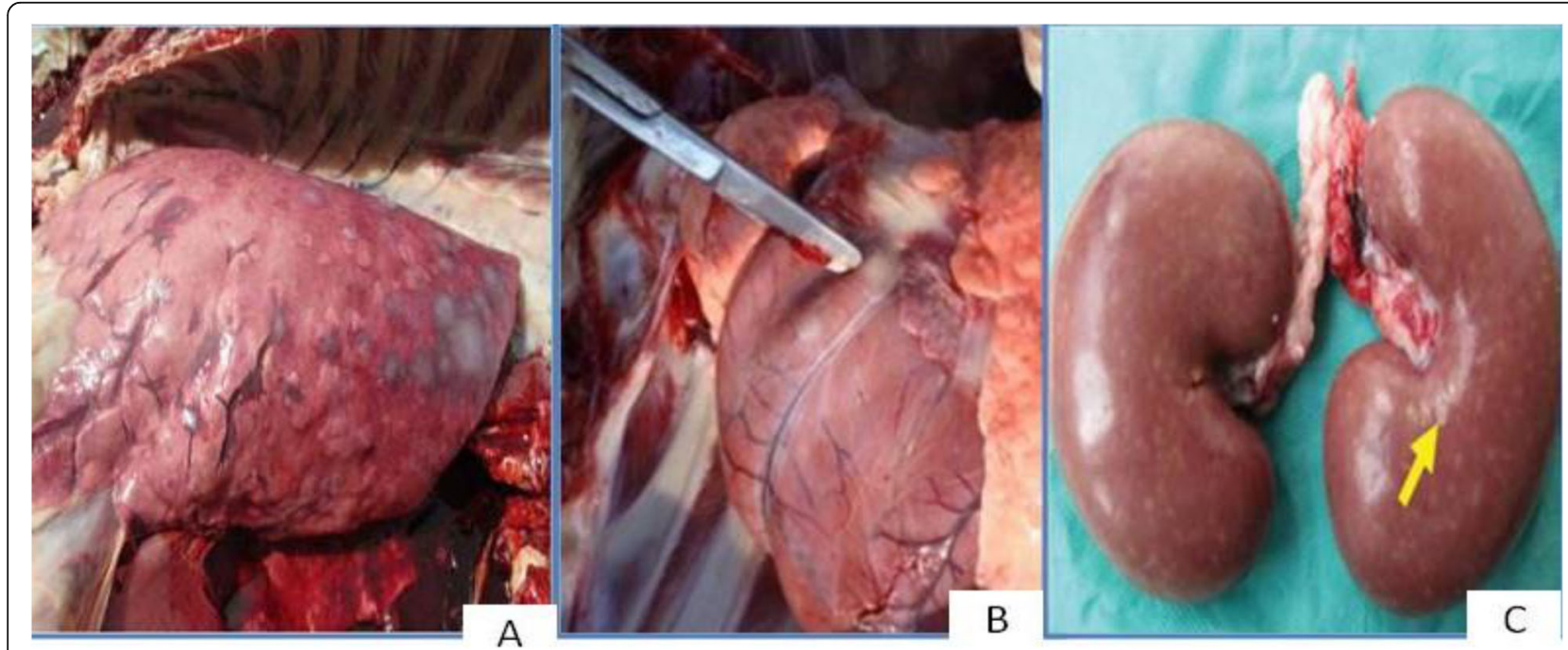

Fig. 3 Pox lesions in $\mathbf{A}$ the lung, $\mathbf{B}$ heart muscles and $\mathbf{C}$ kidney. Source (Courtesy: photograph Colin Scrivener) 


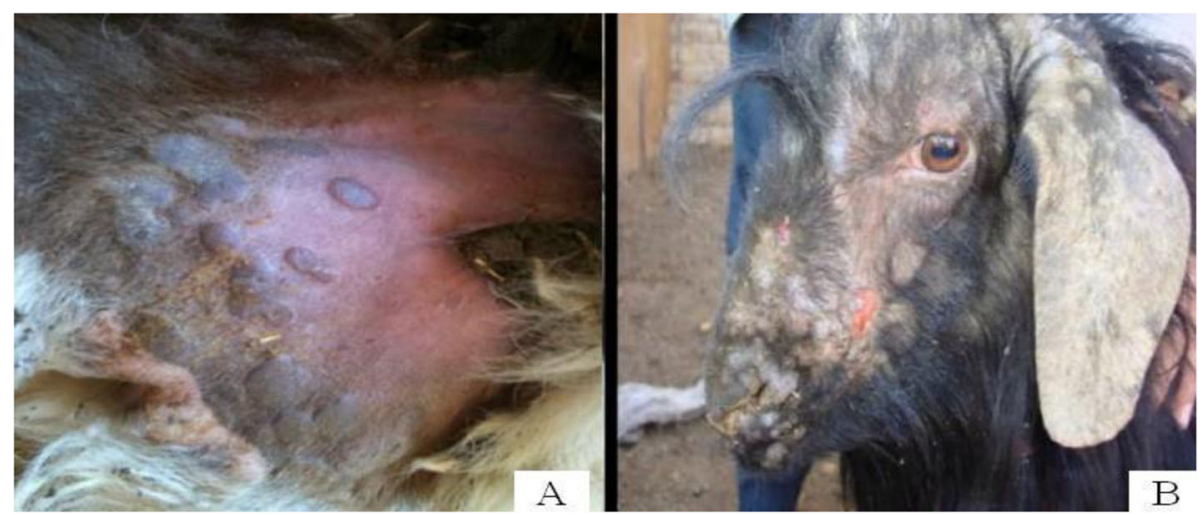

Fig. 4 Popular lesions under the tail (A). Source (Zangana and Abdullah 2013). Pox lesions on the face and ears (B). Source (Mirzaie et al. 2015)

Viral isolation is required to validate the infectivity of the agent. Thus, primary cell lines can be used to isolate SPPV from GTPV (Babiuk et al. 2007). Additionally, PCR is a simple and convenient technique to detect CaPV genomes in tissue samples (Lamien et al. 2011), but it is impossible to discriminate between GTPV and SPPV (Rao and Bandyopadhyay 2000). However, sequencing of the P32 (Zeng et al. 2014) and GpCR genes was used to distinguish these viruses (Yan et al. 2012; Sumana et al. 2020). Additionally, a specific and sensitive duplex PCR technique was applied to the differential analysis of GTPV and SPPV, particularly in resourcelimited endemic countries (Zhao et al. 2017). Likewise, real-time PCR containing a snapback primer and a DNA intercalating dye (Gelaye et al. 2013) and a real-time high-resolution melting PCR assay have been developed (Pestova et al. 2018).

Electron microscopy can distinguish CaPV morphology from parapoxvirus morphology (Balinsky et al. 2008). CaPV can be easily identified by laboratory examinations of other poxviruses that impart similar clinical manifestations in animals. Hence, CaPV strains can be obviously distinguished by genetic sequencing (Lahens et al. 2017; Biswas et al., 2020b). Thus, full genetic sequence examination have revealed that these viruses are distinct from each other and are classified into three distinct groups. However, GTPV and LSDV are more similar than SPPV to LSDV (Le Goff et al. 2009; Lamien et al. 2011). Thus, sequencing of GPCR and P32 has been applied to identify and differentiate LSDV from SPPV and GTPV (Mafirakureva et al. 2017; Salnikov et al. 2018). However, the $P 32$ gene is a better marker than LSDV termini to distinguish different CaPV strains (Sameea Yousefi et al. 2018).

\section{Treatment, control and prevention}

No specific treatment is available for a viral disease, but antibiotics are given for secondary bacterial infection, and good nursing care is recommended to reduce morbidity and other complications (Hajer et al. 1988). Additionally, better consideration of disease occurrence and its distribution would lead to improved control measures (Fentie et al. 2017; Limon et al. 2020). Effective control and eradication of $\mathrm{CaPV}$ of small ruminants in previously CaPV-free countries could be practiced by slaughtering all contaminated and in-contact animals (Tuppurainen and Galon 2016), given that the application of attenuated vaccines in nonendemic areas may not be advantageous (Bowden et al. 2008). However, in many endemic countries, live attenuated vaccines provide longer-term protective immunity than inactivated vaccines (Bhanuprakash et al. 2012; Welfare, E. P. on A. H. and 2014).

Furthermore, live attenuated Capripox vaccines are safe and effective to combat these diseases (Tuppurainen et al. 2017), while inactivated vaccines do not offer prolonged immunity and require two doses (Boumart et al. 2016). Although different studies have shown that, even in the face of adversity (e.g., insufficient protection and short-lived), recent findings strongly support that inactivated Capripox vaccines are safe and efficacious against CaPV (Wolff et al. 2021; Es-sadeqy et al. 2021). In CaPV infection, both antibody and cellular immunity provide lifelong immunity (Bhanuprakash et al. 2006). However, cell-mediated immunity elicits long-term protection (Carn 1993). The close antigenic relationship (which shares 98\% sequence similarity) among SPP, GTP and LSD theoretically allows for a single vaccine to protect against all these diseases (Brenner et al. 2009).

In Ethiopia, annual mass vaccination with the Kenyan sheep and goat pox (KSGP) O-180 virus strains has been demonstrated to be a safe, effective and affordable method to control small ruminant pox virus (Fentie et al. 2017). However, the absence of adequate infrastructure could hinder the implementation of sufficient herd immunity (Mirzaie et al. 2015; Barua et al. 2017). 
In Ethiopia, approximately 22 different types of vaccines have been produced for domestic use and the export market. Among these, the live attenuated (KSGPV) O180 vaccine strain has been manufactured using continuous cell lines (Vero cells) and is a lyophilized vaccine with a stabilizer that is stored at $-20^{\circ} \mathrm{C}$ for 2 years. Although some cattle breeders question whether the KSGP O-180 vaccine provides adequate protection, the KSGP vaccine strain is used currently to control LSD in cattle. However, this strain in Ethiopia is safe and effective in controlling sheep and goat pox if and only if storage, transportation, handling of the vaccines, and sufficient vaccination coverage are properly maintained.

Mutations of ankyrin (ANK) and kelch-like proteins of some of the CaPV vaccine strains have recently been reported. The ANK gene of CaPV makes it a potential candidate to develop a CaPV vaccine. Thus, many live vaccines of $\mathrm{CaPV}$ present a familiar attribute that $A N K$ genes have mutated (Biswas et al. 2020). By contrast, vaccine failure may be associated with insufficient vaccination coverage and the production of lowperformance local vaccines (Gelaye et al. 2015), and attenuated vaccine isolates are clinically secure to control disease in sheep and goats but not in cattle (Ayelet et al. 2013). According to Liu et al. (2019), the characteristics and attenuation properties of the virus strain must be determined while selecting vaccine strains to immunize cattle, sheep and goats. Additionally, CaPV vaccines require evaluation in all animal species to determine the their efficiency (Teffera and Babiuk 2019).

\section{Conclusions}

Sheep pox and goat pox are distributed worldwide, including in Ethiopia. Transmission is thought to facilitated by either direct or indirect contact with respiratory droplets of acutely contaminated animals. SPP and GTP have huge economic consequences for livestock owners in endemic areas and are the main limitations on the international market for live animals and their products. Economic losses are also reflected by decreased meat and milk production, abortion, low quality of wool and skin, and the international trade ban. Many liveattenuated vaccines of CaPV were mutated and ultimately failed to protect animals from infection. Conversely, vaccine failure could be associated with insufficient coverage and vaccine quality. In Ethiopia, the National Veterinary Institute has been working extensively to improve the current KSGP vaccines against these infections. Livestock owners understand the benefits of vaccines and have a strong desire to vaccinate their flocks. However, most livestock owners, particularly in rural areas, have a low level of education, and significant gaps exist regarding the use and management of these vaccines. Additionally, the existing KSGP-based attenuated vaccine whole genomes should be sequenced for the development of new, safe and more efficacious vaccine candidates for small ruminants and cattle to maintain better control of CaPV in the country. Furthermore, awareness-raising campaigns for farmers to promote vaccine management and handling should be considered.

\section{Abbreviations \\ AGID: Agar gel immunodiffusion assay; ANK: Ankyrin; CaPV: Capripoxviruses; ELISA: Enzyme-linked immunosorbent assay; GpCR: G-protein coupled receptor; GTP: Goat pox; GTPV: Goat pox virus; IFAT: Indirect fluorescent antibody test; KSGP: Kenyan sheep and goat pox; LSDV: Lumpy skin disease virus; NVI: National Veterinary Institute; OIE: World Organization for Animal Health; PCR: Polymerase chain reaction; SPP: Sheep pox; SPPV: Sheep pox virus; USD: United States dollar; VNT: Virus neutralization tests}

\section{Acknowledgments}

The authors would like to thank the staff at the National Veterinary Institute who were directly involved in the production of SPP, GTP, and LSD vaccines for their practical and professional assistance with vaccine management during the preparation of this review article.

Authors' contributions

GZ, MA, HB, Getaw D and B G conducted the review and prepared the paper. The original sketch of the review was prepared by $\mathrm{GZ}$, and all the authors observed the preceding versions of the document. The direction of the study and review and editing of the manuscript were performed by MA, $H B, G D$ and $B G$. All the authors evaluated and accepted the last document.

\section{Funding}

No grants were received.

Availability of data and materials

Not applicable.

\section{Declarations}

Ethics approval and consent to participate

This article did not include animal experiments.

Consent for publication

Not applicable.

Competing interests

None.

\section{Author details}

${ }^{1}$ National Veterinary Institute, P. O. Box: 19, Bishoftu, Ethiopia. ${ }^{2}$ Africa Union Pan African Veterinary Vaccine Center (AU-PANVAC), P. O. Box: 1746, Bishoftu, Ethiopia. ${ }^{3}$ Department of Biotechnology, Koneru Lakshmaiah Education

Foundation, Vaddeswaram, Gunture, AP 522502, India.

Received: 14 August 2021 Accepted: 8 October 2021

Published online: 15 November 2021

\section{References}

Afshar, A., A. Bundza, D.J. Myers, G.C. Dulac, and F.C. Thomas. 1986. Sheep pox: Experimental studies with a west african isolate. The Canadian Veterinary Journal = La Revue Veterinaire Canadienne 27 (8): 301-306 http://www.ncbi. nlm.nih.gov/pubmed/17422683\%0A http://www.pubmedcentral.nih.gov/a rticlerender.fcgi?artid=PMC1680293.

Al-Salihi, K.A., and I.Q. Hassan. 2015. Lumpy skin disease in Iraq: Study of the disease emergence. Transboundary and Emerging Diseases 62 (5): 457-462. https://doi.org/10.1111/tbed.12386.

Aregahagn, S., B. Tadesse, B. Tegegne, Y. Worku, and S. Mohammed. 2021. Spatiotemporal distributions of sheep and goat pox disease outbreaks in the period 2013-2019 in Eastern Amhara Region, Ethiopia. Veterinary Medicine International 2021: 1-7. https://doi.org/10.1155/2021/6629510. 
Ayelet, G., Y. Abate, T. Sisay, H. Nigussie, E. Gelaye, S. Jemberie, and K. Asmare 2013. Lumpy skin disease: Preliminary vaccine efficacy assessment and overview on outbreak impact in dairy cattle at Debre Zeit, central Ethiopia. Antiviral Research 98 (2): 261-265. https://doi.org/10.1016/j.antiviral.2013.02. 008.

Babiuk, S., T.R. Bowden, D.B. Boyle, D.B. Wallace, and R.P. Kitching. 2008. Capripoxviruses: An emerging worldwide threat to sheep, goats and cattle. Transboundary and Emerging Diseases 55 (7): 263-272. https://doi.org/1 0.1111/j.1865-1682.2008.01043.X.

Babiuk, S., D.B. Wallace, S.J. Smith, T.R. Bowden, B. Dalman, G. Parkyn, J. Copps, and D.B. Boyle. 2009a. Detection of antibodies against capripoxviruses using an inactivated sheeppox virus ELISA. Transboundary and Emerging Diseases 56 (4): 132-141. https://doi.org/10.1111/j.1865-1682.2009.01067.x.

Babiuk, Shawn, T.R. Bowden, G. Parkyn, B. Dalman, D.M. Hoa, N.T. Long, P.P. Vu, D. X. Bieu, J. Copps, and D.B. Boyle. 2009b. Yemen and Vietnam capripoxviruses demonstrate a distinct host preference for goats compared with sheep. Journal of General Virology 90 (1): 105-114. https://doi.org/10.1099/vir.0.004 507-0.

Babiuk, Shawn, G. Parkyn, J. Copps, J.E. Larence, M.I. Sabara, T.R. Bowden, D.B. Boyle, and R.P. Kitching. 2007. Evaluation of an ovine testis cell line (OA3. Ts ) for propagation of capripoxvirus isolates and development of an immunostaining technique for viral plaque visualization. Journal of Veterinary Diagnostic Investigation 491: 486-491.

Balinsky, C.A., G. Delhon, C.L. Afonso, G.R. Risatti, M.V. Borca, R.A. French, E.R. Tulman, S.J. Geary, and D.L. Rock. 2007. Sheeppox virus kelch-like gene SPPV019 affects virus virulence. Journal of Virology 81 (20): 11392-11401. https:// doi.org/10.1128/jvi.01093-07.

Balinsky, C.A., G. Delhon, G. Smoliga, M. Prarat, R.A. French, S.J. Geary, D.L. Rock, and L.L. Rodriguez. 2008. Rapid preclinical detection of sheeppox virus by a real-time PCR assay. Journal of Clinical Microbiology 46 (2): 438-442. https:// doi.org/10.1128/JCM.01953-07.

Barua, N., B.C. Sutradhar, S. Chowdhury, and A. Al. 2017. A case report on management of goat pox of a doe in Rangamati, Chittagong.

Beard, P.M., S. Sugar, E. Bazarragchaa, U. Gerelmaa, S.H.S. Tserendorj, E. Tuppurainen, and R. Sodnomdarjaa. 2010. Short communication. A description of two outbreaks of capripoxvirus disease in Mongolia. Veterinary Microbiology 142 (3-4): 427-431. https://doi.org/10.1016/j.vetmic.2009.10.018 Elsevier B.V.

Bhanuprakash, V., M. Hosamani, and R.K. Singh. 2011. Prospects of control and eradication of capripox from the Indian subcontinent: A perspective. Antiviral Research 91 (3): 225-232. https://doi.org/10.1016/j.antiviral.2011.06.004.

Bhanuprakash, V., B.K. Indrani, M. Hosamani, and R.K. Singh. 2006. The current status of sheep pox disease. Comparative Immunology, Microbiology and Infectious Diseases 29 (1): 27-60. https://doi.org/10.1016/j.cimid.2005.12.001.

Bhanuprakash, V., G. Venkatesan, V. Balamurugan, M. Hosamani, R. Yogisharadhya, R.S. Chauhan, A. Pande, B. Mondal, and R.K. Singh. 2010. Pox outbreaks in sheep and goats at Makhdoom (Uttar Pradesh), India: evidence of sheeppox virus infection in goats. Transboundary and Emerging Diseases 57 (5): 375 382. https://doi.org/10.1111/j.1865-1682.2010.01158.x.

Bhanuprakash, Veerakyathappa, M. Hosamani, G. Venkatesan, V. Balamurugan, R. Yogisharadhya, and R.K. Singh. 2012. Animal poxvirus vaccines: a comprehensive review. Expert Review of Vaccines 11 (11): 1355-1374. https:// doi.org/10.1586/erv.12.116

Biswas, S., R.S. Noyce, L.A. Babiuk, O. Lung, D.M. Bulach, T.R. Bowden, D.B. Boyle, S. Babiuk, and D.H. Evans. 2020. Extended sequencing of vaccine and wild-type capripoxvirus isolates provides insights into genes modulating virulence and host range. Transboundary and Emerging Diseases 67 (1): 80-97. https://doi. org/10.1111/tbed.13322.

Boumart, Z., S. Daouam, I. Belkourati, L. Rafi, E. Tuppurainen, K.O. Tadlaoui, and M. El Harrak. 2016. Comparative innocuity and efficacy of live and inactivated sheeppox vaccines. BMC Veterinary Research 12 (1): 1-6. https://doi.org/10.11 86/s12917-016-0754-0.

Bowden, T.R., S.L. Babiuk, G.R. Parkyn, J.S. Copps, and D.B. Boyle. 2008. Capripoxvirus tissue tropism and shedding: A quantitative study in experimentally infected sheep and goats. Virology 371 (2): 380-393. https:// doi.org/10.1016/j.virol.2007.10.002.

Brenner, J., M. Bellaiche, E. Gross, D. Elad, Z. Oved, M. Haimovitz, A. Wasserman, O. Friedgut, Y. Stram, V. Bumbarov, and H. Yadin. 2009. Appearance of skin lesions in cattle populations vaccinated against lumpy skin disease: Statutory challenge. Vaccine 27 (10): 1500-1503. https://doi.org/10.1016/j.vaccine.2009. 01.020 .
Calistri, P., K. DeClercq, A. De Vleeschauwer, S. Gubbins, E. Klement, A. Stegeman, J. Cortiñas Abrahantes, S.E. Antoniou, A. Broglia, and A. Gogin. 2018. Lumpy skin disease: Scientific and technical assistance on control and surveillance activities. EFSA Journal 16 (10): e05452. https://doi.org/10.2903/j.efsa.2018.54 52.

Carn, V.M. 1993. Control of capripoxvirus infections. Vaccine 11 (13): 1275-1279. https://doi.org/10.1016/0264-410X(93)90094-E.

Chibssa, T.R., T.B.K. Settypalli, F.J. Berguido, R. Grabherr, A. Loitsch, E. Tuppurainen, N. Nwankpa, K. Tounkara, H. Madani, A. Omani, M. Diop, G. Cattoli, A. Diallo, and C.E. Lamien. 2019. An HRM assay to differentiate sheeppox virus vaccine strains from sheeppox virus field isolates and other capripoxvirus species. Scientific Reports 9 (1): 1-9. https://doi.org/10.1038/s41598-019-43158-x.

CSA. 2020. Central Statistical Authority of Ethiopia: Report on livestock and livestock characteristics (private peasant holdings). Vol. II (March), 1-228.

Davies, F.G. 1982. Observations on the epidemiology of lumpy skin disease in Kenya. Journal of Hygiene 88 (1): 95-102. https://doi.org/10.1017/S00221724 0006993X.

Domenech, J., J. Lubroth, C. Eddi, V. Martin, and F. Roger. 2006. Regional and international approaches on prevention and control of animal transboundary and emerging diseases. Annals of the New York Academy of Sciences 1081 (1): 90-107. https://doi.org/10.1196/annals.1373.010.

Embury-Hyatt, C., S. Babiuk, L. Manning, S. Ganske, T.R. Bowden, D. Boyle, and J. Copps. 2012. Pathology and viral antigen distribution following experimental infection of sheep and goats with capripoxvirus. Journal of Comparative Pathology 146 (2-3): 106-115. https://doi.org/10.1016/j.jcpa.2011.12.001.

Entity, T.M. 2016. Feed the future innovation lab for livestock systems Ethiopia: livestock disease management and food safety brief. Vol. May, 75-100.

Es-sadeqy, Y., Z. Bamouh, A. Ennahli, N. Safini, S. El Mejdoub, K. Omari Tadlaoui, B. Gavrilov, and M. El Harrak. 2021. Development of an inactivated combined vaccine for protection of cattle against lumpy skin disease and bluetongue viruses. Veterinary Microbiology 256: 109046. https://doi.org/10.1016/j.vetmic.2 021.109046.

FAO. 2017a. Lumpy skin disease: Situation, surveillance and control activities in Turkey. EMPRES Animal Health 36047 (November) http://www.fao.org/publica tions/card/en/c/5d0b5cfa-5999-49e1-8ee8-c2a1943a0390/.

FAO. (2017b). Lumpy skin disease (LSD) field manual for veterinarians. http:// www.fao.org/3/a-i7330e.pdf

FAO. 2019. The future of livestock in Ethiopia. Opportunities and challenges in the face of uncertainty, 48. Rome.

Fentie, T., N. Fenta, S. Leta, W. Molla, B. Ayele, Y. Teshome, S. Nigatu, and A. Assefa. 2017. Sero-prevalence, risk factors and distribution of sheep and goat pox in Amhara Region, Ethiopia. BMC Veterinary Research 13 (1): 1-9. https:// doi.org/10.1186/s12917-017-1312-0.

Gari, G., F. Biteau-Coroller, C. LeGoff, P. Caufour, and F. Roger. 2008. Evaluation of indirect fluorescent antibody test (IFAT) for the diagnosis and screening of lumpy skin disease using Bayesian method. Veterinary Microbiology 129 (3-4): 269-280. https://doi.org/10.1016/j.vetmic.2007.12.005.

Gari, Getachew, G. Mekonnen, D. Sibhat, A. Abebe, M. Sahle, and G. Abie. 2015. Participatory disease surveillance (PDS) of sheep and goats deseases in selected districts of Afar Regional State: Particular focus on Pestes des petit ruminants (PPR) and sheep and goat pox disease (SGP). Ethiopian Veterinary Journal 19 (1): 83-105 Ethiopian Veterinary Association.

Gelaye, E., A. Belay, G. Ayelet, S. Jenberie, M. Yami, A. Loitsch, E. Tuppurainen, R. Grabherr, A. Diallo, and C.E. Lamien. 2015. Capripox disease in Ethiopia: Genetic differences between field isolates and vaccine strain, and implications for vaccination failure. Antiviral Research 119: 28-35. https://doi. org/10.1016/J.ANTIVIRAL.2015.04.008.

Gelaye, E., C.E. Lamien, R. Silber, E.S.M. Tuppurainen, R. Grabherr, and A. Diallo. 2013. Development of a cost-effective method for capripoxvirus genotyping using snapback primer and dsDNA intercalating dye. 8 (10): 1-10. https://doi. org/10.1371/journal.pone.0075971.

Gitao, C.G., C. Mbindyo, R. Omani, and V. Chemweno. 2017. Review of sheep pox disease in sheep. Journal of Veterinary Medicine and Research 4: 1-5.

Haegeman, A., K. Zro, D. Sammin, F. Vandenbussche, M.M. Ennaji, and K. De Clercq. 2016. Investigation of a possible link between vaccination and the 2010 sheep pox epizootic in Morocco. Transboundary and Emerging Diseases 63 (6): e278-e287. https://doi.org/10.1111/tbed.12342.

Haile, A., S. Gizaw, T. Getachew, and B. Rischkowsky. 2018. Challenges in small ruminant breeding programs and resulting investment priorities in Ethiopia. In Proceedings of the World Congress on Genetics Applied to Livestock Production, Genetic ga(1), 475. 
Hajer, I., B. Abbas, and M.T. Abu Samra. 1988. Capripox virus in sheep and goats in Sudan. Revue d'elevage et de Medecine Veterinaire Des Pays Tropicaux 41 (2): $125-128$.

Haller, S.L., C. Peng, G. McFadden, and S. Rothenburg. 2014. Poxviruses and the evolution of host range and virulence. Infection, Genetics and Evolution 21: 15-40. https://doi.org/10.1016/j.meegid.2013.10.014.

Hamdi, J., H. Munyanduki, K.O. Tadlaoui, M. El Harrak, and O.F. Fihri. 2021. Capripoxvirus infections in ruminants: A review. Microorganisms 9 (5): 1-16. https://doi.org/10.3390/microorganisms9050902

He, C., J. Tong, X. Zhang, M. Tuohetiniyazi, Y. Zhang, and Y. Li. 2020. Comparative analysis of ankyrin (ANK) genes of five capripoxviruses isolate strains from Xinjiang province in China. Virology Journal 17 (1): 1-18 10.1186/s12985-02001407-w.

Hopker, A., N. Pandey, D. Saikia, J. Goswami, S. Hopker, R. Saikia, and N. Sargison. 2019. Spread and impact of goat pox ("sagolay bohonta") in a village smallholder community around Kaziranga National Park, Assam, India. Tropical Animal Health and Production 51 (4): 819-829 10.1007/s11250-0181759-4

Hosamani, M., B. Mondal, P.A. Tembhurne, S.K. Bandyopadhyay, R.K. Singh, and T. J. Rasool. 2004. Differentiation of sheep pox and goat poxviruses by sequence analysis and PCR-RFLP of P32 gene. Virus Genes 29 (1): 73-80 10. 1023/B:VIRU.0000032790.16751.13

Kebede, A., E. Hailemariam, and J. Dugassa. 2018. Prevalence of common skin diseases of small ruminants in Dibate district Metekel zone Beneshangul Gumuz Regional State Northwestern Ethiopia. Scientia Ricerca Open Access Directory 2 (April): 2-3.

Kenubih, A., B. Mammo, G. Terefe, and T. Fentahun. 2021. Assessment of the impact of sheep and goat pox lesions on skin quality in selected ware houses of central Ethiopia. Veterinary Medicine: Research and Reports 12: 199204. https://doi.org/10.2147/vmrr.s305705.

King, A.M.Q., M.J. Adams, E.B. Carstens, and E.J. Lefkowitz. 2012. Virus taxonomy. In Ninth report of the International Committee on Taxonomy of Viruses, vol. 9.

Kitching, R.P., J.J. McGrane, and W.P. Taylor. 1986. Capripox in the Yemen Arab Republic and the Sultanate of Oman. Tropical Animal Health and Production 18 (2): 115-122. https://doi.org/10.1007/BF02359725.

Lahens, N.F., E. Ricciotti, O. Smirnova, E. Toorens, E.J. Kim, G. Baruzzo, K.E. Hayer, T. Ganguly, J. Schug, and G.R. Grant. 2017. A comparison of Illumina and lon Torrent sequencing platforms in the context of differential gene expression. BMC Genomics 18 (1): 602. https://doi.org/10.1186/s12864-017-4011-0.

Lamien, C.E., C. Le Goff, R. Silber, D.B. Wallace, V. Gulyaz, E. Tuppurainen, H. Madani, P. Caufour, T. Adam, M. El Harrak, A.G. Luckins, E. Albina, and A. Diallo. 2011. Use of the Capripoxvirus homologue of Vaccinia virus 30kDa RNA polymerase subunit (RPO30) gene as a novel diagnostic and genotyping target: Development of a classical PCR method to differentiate Goat poxvirus from Sheep poxvirus. Veterinary Microbiology 149 (1): 30-39. https://doi.org/10.1016/j.vetmic.2010.09.038

Le Goff, C., C.E. Lamien, E. Fakhfakh, A. Chadeyras, E. Aba-adulugba, G. Libeau, E. Tuppurainen, D.B. Wallace, T. Adam, R. Silber, V. Gulyaz, H. Madani, P. Caufour, S. Hammami, A. Diallo, E. Albina, C. Le Goff, C.E. Lamien, E. Fakhfakh, et al. 2009. Capripoxvirus G-protein-coupled chemokine receptor: A host-range gene suitable for virus animal origin discrimination. Journal of General Virology 90 (8): 1967-1977. https://doi.org/10.1099/vir.0.010686-0.

Limon, G., A.A. Gamawa, A.I. Ahmed, N.A. Lyons, and P.M. Beard. 2020. Epidemiological characteristics and economic impact of lumpy skin disease, sheeppox and goatpox among subsistence farmers in northeast Nigeria. Frontiers in Veterinary Science 7 (January): 1-13. https://doi.org/10.3389/fvets.2 020.00008 .

Liu, F., H. Zhang, and W. Liu. 2019. Construction of recombinant capripoxviruses as vaccine vectors for delivering foreign antigens: Methodology and application. Comparative Immunology, Microbiology and Infectious Diseases 65 (May): 181-188. https://doi.org/10.1016/j.cimid.2019.05.013.

Mafirakureva, P., B. Saidi, and J. Mbanga. 2017. Incidence and molecular characterisation of lumpy skin disease virus in Zimbabwe using the P32 gene. Tropical Animal Health and Production 49 (1): 47-54. https://doi.org/1 0.1007/s11250-016-1156-9.

Mahmoud, M.A., and M.H. Khafagi. 2016. Detection, identification, and differentiation of sheep pox virus and goat pox virus from clinical cases in Giza Governorate, Egypt. Veterinary World 9 (12): 1445-1449. https://doi.org/1 0.14202/vetworld.2016.1445-1449.

Maksyutov, R.A., E.V. Gavrilova, A.P. Agafonov, O.S. Taranov, A.G. Glotov, V.N. Miheev, S.N. Shchelkunov, and A.N. Sergeev. 2015. An outbreak of sheep pox in Zabajkalskij kray of Russia. Transboundary and Emerging Diseases 62 (4): 453-456. https://doi.org/10.1111/tbed.12176.

Milovanović, M., K. Dietze, V. Milićević, S. Radojičić, M. Valčić, T. Moritz, and B. Hoffmann. 2019. Humoral immune response to repeated lumpy skin disease virus vaccination and performance of serological tests. BMC Veterinary Research 15 (1): 80. https://doi.org/10.1186/s12917-019-1831-y.

Mirzaie, K., S.M. Barani, and S. Bokaie. 2015. A review of sheep pox and goat pox: Perspective of their control and eradication in Iran. Journal of Advanced Veterinary and Animal Research 2 (4): 373-381. https://doi.org/10.5455/javar.2 015.b117.

MOA. 2013. Animal health strategy and vision for Ethiopia, 1-18 http://www.moa. gov.et/home

Molla, B., H. Haile, and S. Alemu. 2017a. Prevalence and risk factors associated to skin diseases in small ruminants in Gamo Gofa zone, south-Western Ethiopia. Journal of Veterinary Medicine and Animal Health 9 (8): 228-234. https://doi. org/10.5897/JVMAH2015.0375.

Molla, W., M.C.M. de Jong, G. Gari, and K. Frankena. 2017b. Economic impact of lumpy skin disease and cost effectiveness of vaccination for the control of outbreaks in Ethiopia. Preventive Veterinary Medicine 147 (May): 100-107. https://doi.org/10.1016/j.prevetmed.2017.09.003.

Moss, B., Mackett, M., \& Smith, G. L. (2006). Recombinant poxviruses having foreign DNA expressed under the control of poxvirus regulatory sequences. Google Patents.

OIE. 2008. Sheep pox and goat pox. In Sheep and goat pox Ch 2.7.14, August, 1058-1068 http://www.cabdirect.org/abstracts/19842238269.html.

OIE. 2010. Lumpy skin disease, 1-13.

Pestova, Y., O. Byadovskaya, A. Kononov, and A. Sprygin. 2018. A real time highresolution melting PCR assay for detection and differentiation among sheep pox virus, goat pox virus, field and vaccine strains of lumpy skin disease virus. Molecular and Cellular Probes 41: 57-60. https://doi.org/10.1016/j.mcp.2 018.08.003.

Pham, T.H., M.A.M. Lila, N.Y.A. Rahaman, H.L.T. Lai, L.T. Nguyen, K. Van Do, and M. M. Noordin. 2020. Epidemiology and clinico-pathological characteristics of current goat pox outbreak in North Vietnam. BMC Veterinary Research 16 (1): 1-9. https://doi.org/10.1186/s12917-020-02345-z.

Rao, T.V., and S.K. Bandyopadhyay. 2000. A comprehensive review of goat pox and sheep pox and their diagnosis. Animal Health Research Reviews / Conference of Research Workers in Animal Diseases 1 (2): 127-136. https://doi. org/10.1017/S1466252300000116.

Rouby, S.R. 2018. RPO30 Gene based PCR for detection and differentiation of lumpy skin disease virus and sheep poxvirus field and vaccinal strains. Veterinary Sciences: Research and Reviews 4 (1). https://doi.org/10.17582/journa I.vsrr/2018.4.1.1.8

Salnikov, N., T. Usadov, A. Kolcov, S. Zhivoderov, Y. Morgunov, V. Gerasimov, A. Gogin, I. Titov, S. Yurkov, A. Malogolovkin, D. Kolbasov, and A. Lunitsyn. 2018. Identification and characterization of lumpy skin disease virus isolated from cattle in the Republic of North Ossetia-Alania in 2015. Transboundary and Emerging Diseases 65 (3): 916-920. https://doi.org/10.1111/tbed.12818.

Sameea Yousefi, P., B. Dalir-Naghadeh, K. Mardani, and G. Jalilzadeh-Amin. 2018 Phylogenetic analysis of the lumpy skin disease viruses in northwest of Iran. Tropical Animal Health and Production 50 (8): 1851-1858. https://doi.org/10.1 007/s11250-018-1634-3.

Schramm, B., and J.K. Locker. 2005. Cytoplasmic organization of POXvirus DNA replication. Traffic 6 (10): 839-846. https://doi.org/10.1111/j.1600-0854.2005.00324.x.

Şevik, M., O. Avci, M. Doğan, and Ö.B. Ince. 2016. Serum biochemistry of lumpy skin disease virus-infected cattle. BioMed Research International 2016: 1-6. https://doi.org/10.1155/2016/6257984.

Sprygin, A., Y. Pestova, D.B. Wallace, E. Tuppurainen, and A.V. Kononov. 2019. Transmission of lumpy skin disease virus: A short review. Virus Research 269: 197637. https://doi.org/10.1016/j.virusres.2019.05.015.

Sumana, K., Y. Revanaiah, R. Apsana, P. Roy, and G.B. Manjunatha Reddy. 2020 Molecular characterization of sheeppox virus from outbreaks in Karnataka, India. Veterinary World 13 (2): 386-391. https://doi.org/10.14202/vetworld.202 0.386-391.

Teffera, M., and S. Babiuk. 2019. Potential of using capripoxvirus vectored vaccines against arboviruses in sheep, goats, and cattle. Frontiers in Veterinary Science 6 (December): 1-12. https://doi.org/10.3389/fvets.2019.00450.

Tuppurainen, E., and N. Galon. 2016. Lumpy skin disease: current situation in \{Europe\} and neighbouring regions and necessary control measures to halt the spread in south-east \{Europe\}. 2016: 1-12. https://doi.org/10.20506/TT.2 554. 
Tuppurainen, E.S.M., E.H. Venter, J.L. Shisler, G. Gari, G.A. Mekonnen, N. Juleff, N.A. Lyons, K. De Clercq, C. Upton, T.R. Bowden, S. Babiuk, and L.A. Babiuk. 2017. Review: Capripoxvirus diseases: Current status and opportunities for control. Transboundary and Emerging Diseases 64 (3): 729-745. https://doi.org/1 $0.1111 /$ tbed.12444.

Tuppurainen, E.S.M.M., and C.A.L.L. Oura. 2012. Review: Lumpy skin disease: An emerging threat to Europe, the Middle East and Asia. Transboundary and Emerging Diseases 59 (1): 40-48. https://doi.org/10.1111/j.1865-1682.2011. 01242.x.

Tuppurainen, Eeva S.M., S. Babiuk, and E. Klement. 2018. Lumpy skin disease. Lumpy Skin Disease 16 (11): 1-109. https://doi.org/10.1007/978-3-319-92411-3.

Tuppurainen, Eeva S.M., C.R. Pearson, K. Bachanek-Bankowska, N.J. Knowles, S. Amareen, L. Frost, M.R. Henstock, C.E. Lamien, A. Diallo, and P.P.C.C. Mertens. 2014. Characterization of sheep pox virus vaccine for cattle against lumpy skin disease virus. Antiviral Research 109 (1): 1-6. https://doi.org/10.1016/j.a ntiviral.2014.06.009

Tuppurainen, Eeva, E.H. Venter, and J.L. Shisler. 2015. Review: Capripoxvirus diseases: Current status and opportunities for control. Transboundary and Emerging Diseases 64 (3): 729-745. https://doi.org/10.1111/tbed.12444.

USDA. (2016). Sheep and goat pox standard operating procedures: Overview of etiology and ecology.

Venkatesan, G., V. Balamurugan, R. Yogisharadhya, A. Kumar, and V. Bhanuprakash. 2012. Differentiation of sheeppox and goatpox viruses by polymerase Chain reaction-restriction fragment length polymorphism. Virologica Sinica 27 (6): 352-358. https://doi.org/10.1007/s12250-012-3277-2.

Verma, S., L.K. Verma, V.K. Gupta, V.C. Katoch, V. Dogra, B. Pal, and M. Sharma. 2011. Emerging Capripoxvirus disease outbreaks in Himachal Pradesh, a Northern State of India. Transboundary and Emerging Diseases 58 (1): 79-85. https://doi.org/10.1111/j.1865-1682.2010.01172.x.

Welfare, E. P. on A. H. and. 2014. Scientific opinion on sheep and goat pox. EFSA Journal 12 (11): 3885. https://doi.org/10.2903/j.efsa.2014.3885.

Wolff, J., J. King, T. Moritz, A. Pohlmann, D. Hoffmann, M. Beer, and B. Hoffmann. 2020. Experimental infection and genetic characterization of two different capripox virus isolates in small ruminants. Viruses 12 (10). https://doi.org/10.33 90/v12101098.

Wolff, J., T. Moritz, K. Schlottau, D. Hoffmann, M. Beer, and B. Hoffmann. 2021. Development of a safe and highly efficient inactivated vaccine candidate against lumpy skin disease virus. Vaccines 9 (1): 1-30. https://doi.org/10.3390/ vaccines 9010004

Yacob, H.T., B. Nesanet, and A. Dinka. 2008. Part II: Prevalences of major skin diseases in cattle, sheep and goats at Adama Veterinary Clinic, Oromia regional state, Ethiopia, 455-461.

Yan, X.-M., Y.-F. Chu, G.-H. Wu, Z.-X. Zhao, J. Li, H.-X. Zhu, and Q. Zhang. 2012. An outbreak of sheep pox associated with goat poxvirus in Gansu province of China. Veterinary Microbiology 156 (3): 425-428. https://doi.org/10.1016/j. vetmic.2011.11.015

Yeruham, I., H. Yadin, M. Van Ham, V. Bumbarov, A. Soham, S. Perl, M. Van Ham, V. Bumbarov, A. Soham, and S. Perl. 2007. Economic and epidemiological aspects of an outbreak of sheeppox in a dairy sheep flock. Veterinary Record 160 (7): 236-237. https://doi.org/10.1136/vr.160.7.236.

Yune, N., and N. Abdela. 2017. Epidemiology and economic importance of sheep and goat pox: A review on past and current aspects. Journal of Veterinary Science and Technology 8 (2): 1-6. https://doi.org/10.4262/2157-7579.1000430.

Zangana, I.K., and M.A. Abdullah. 2013. Epidemiological, clinical and histopathological studies of lamb and kid pox in Duhok, Iraq. Bulgarian Journal of Veterinary Medicine 16 (2): 133-138.

Zemene, Z., and A. Mekonnen. 2012. Assessment of major factors that cause skin defects at Bahir Dar Tannery. Advances in Biological Research 6 (5): 177-181. https://doi.org/10.5829/idosi.abr.2012.6.5.6636

Zeng, X., X. Chi, W. Li, W. Hao, M. Li, X. Huang, Y. Huang, D.L. Rock, S. Luo, and S. Wang. 2014. Complete genome sequence analysis of goatpox virus isolated from China shows high variation. Veterinary Microbiology 173 (1): 38-49. https://doi.org/10.1016/j.vetmic.2014.07.013.

Zhao, Z., G. Wu, X. Yan, X. Zhu, J. Li, H. Zhu, Z. Zhang, and Q. Zhang. 2017. Development of duplex PCR for differential detection of goatpox and sheeppox viruses. BMC Veterinary Research 13 (1): 1-7. https://doi.org/10.11 86/s12917-017-1179-0.

\section{Publisher's Note}

Springer Nature remains neutral with regard to jurisdictional claims in published maps and institutional affiliations.

\section{Ready to submit your research? Choose BMC and benefit from}

- fast, convenient online submission

- thorough peer review by experienced researchers in your field

- rapid publication on acceptance

- support for research data, including large and complex data types

- gold Open Access which fosters wider collaboration and increased citations

- maximum visibility for your research: over $100 \mathrm{M}$ website views per year

At BMC, research is always in progress.

Learn more biomedcentral.com/submissions 